\title{
Geochemistry of Altungol cap dolostones from the Tarim Basin, NW China
}

\author{
Fan Feng ${ }^{1} \cdot$ Ping Guan ${ }^{1} \cdot$ Wenhui Liu ${ }^{2} \cdot$ Wei Zhang ${ }^{1} \cdot$ \\ Peixian Liu ${ }^{1} \cdot$ Xing Jian ${ }^{1} \cdot$ Ling Fu ${ }^{1}$
}

Received: 29 December 2015 / Accepted: 19 October 2016/Published online: 21 November 2016

(C) The Author(s) 2016. This article is published with open access at Springerlink.com

\begin{abstract}
The Snowball Earth hypothesis postulates that the whole earth was covered by ice sheets for millions of years in the Neoproterozoic. In Tarim Basin, there are four intervals of glacial deposits recorded in the Quruqtagh area during the Neoproterozoic. In chronological order, they are Bayisi, Altungol, Tereeken, and Hankalchough glaciations. In this study, we analyzed carbon, oxygen, and strontium isotopes; whole-rock geochemistry; and acid-insoluble residua of the $\sim 5$-m-thick Altungol cap dolostone (ten samples) in Quruqtagh unit of the Tarim basin. The geochemical data of whole rock are used to explain the ocean environmental changes, while the geochemical data of acid-insoluble residua
\end{abstract}

Ping Guan

pguan1@pku.edu.cn

Fan Feng

1zff1987@163.com

Wenhui Liu

Whliu.syky@sinopec.com

Wei Zhang

zhangwei1863@pku.edu.cn

Peixian Liu

liupeixian6@163.com

Xing Jian

xjian@pku.edu.cn

Ling Fu

Fuling_peking@163.com

1 Key Laboratory of Orogenic Belts and Crustal Evolution, Ministry of Education, School of Earth and Space Sciences, Peking University, Beijing 100871, People's Republic of China

2 Key Laboratory of Petroleum Accumulation Mechanisms, SINOPEC, Wuxi, Jiangsu 213151, People's Republic of China reflect the changes of the continental environment. The $\delta^{13} \mathrm{C}_{\mathrm{PDB}}$ of cap dolostone varies from -2.5 to $-1 \%$, which is likely due to the influence of organics. From the bottom to the top of the Altungol cap dolostones, the chemical index of alteration of acid-insoluble residua rises from 72 to 77 , but the index of chemical variation drops from $\sim 3$ to $\sim 1 . \mathrm{Ni}, \mathrm{Zn}, \mathrm{Cu}$, and $\mathrm{Y}$ contents of acid-insoluble residua are enriched in $2.5 \mathrm{~m}$. The values of iron maintain at a high level in all of the wholerock samples $(>5.15 \%)$, but in the samples of acid-insoluble residua, the values of iron are higher than in the whole rock (19 60\%) below $1.5 \mathrm{~m}$. The variations in chemical composition were probably associated with the changes of continental weathering. The geochemistry suggests that ocean and continent environmental variations had taken place after the Altungol glaciation, including the destruction of ocean stratification and the changes of chemical weathering. During this period, the source of this area had changed. At first, the weathering residues of the parent rocks were exhausted by meltwater. Then, the vigorous weathering of freshly exposed continental crust provided a new source.

Keywords Snowball Earth $\cdot \delta^{13} \mathrm{C} \cdot{ }^{87} \mathrm{Sr} /{ }^{86} \mathrm{Sr} \cdot$ Acid-insoluble residua $\cdot$ Tarim

\section{Introduction}

During Neoproterozoic, the Earth likely underwent at least four global glaciations (i.e. Snowball Earth), including the Kaigas (Frimmel et al. 1996), Sturtian (Allen et al. 2002), Marinoan (Hoffmann et al. 2004), and Gaskiers (Bowring et al. 2003). The Snowball Earth hypothesis (Kirschvink 1992; Hoffman et al. 1998) proposed that ice sheets covered all continents and oceans, even extended to the sea level near the equator. 
Most Neoproterozoic glacial deposits are capped by carbonates usually deposited in warm-water environments (Evans 2000; Porter et al. 2004; Hoffman 2011). The glacial deposits terminated abruptly with the deposition of cap carbonates, which constitutes the sudden change of lithofacies. This sudden change in lithofacies implies dramatic environmental changes during the thawing of a Snowball Earth event (Williams 1979; Hoffman et al. 1998). The trigger(s) of Snowball glaciation and deglaciation, as well as the resulting physical and chemical perturbations to the post-glacial ocean-atmosphere environment, remains a topic of considerable debate (Grozinger and Knoll 1995; Kennedy et al. 1998, 2001; Hoffman et al. 1998; Fairchild and Kennedy 2007; Hoffman and Li 2009; Hoffman 2011). Carbon and sulfur isotope chemostratigraphic data imply rapid post-glacial changes in marine circulation and chemical stratification (Shen et al. 2005, 2008, 2010; Giddings and Wallace 2009). Ratios of Fe/S are considered evidence for increased surface runoff from enhanced rainfall during a post-Snowball greenhouse environment (Bao et al. 2008; Swanson-Hysell et al. 2010).

This study presents stable isotope, major, and trace metal concentrations of a Sturtian-aged cap dolostone overlying the Altungol glacial strata (Gao and Chen 2003; Xu et al. 2009; Hoffman and Li 2009; Gao et al. 2010). The data of $\delta^{13} \mathrm{C}_{\text {carb }}$ chemostratigraphy reported by Kou et al. (2008) suggested that Altungol Formation may be similar to the most intensively studied Sturtian cap carbonate in the Rasthof Formation, Namibia (Hurtgen et al. 2002; Macdonald et al. 2010a, b; Hoffman 2011), and other post-Sturtian cap dolostones (Giddings and Wallace 2009).

In this study, new geochemical results of the whole rock and acid-insoluble residua of Altungol cap dolostones are reported. All of these geochemical data can be explained by a coupling environmental change in post-glacial ocean and continent, in the Tarim Basin. The isotopic and chemical composition of dolostones can be used to explain the environmental changes in post-glacial ocean. The elemental geochemistry of acid-insoluble residua reflects the environmental changes of post-glacial continent.

\section{Regional geology}

The Quruqtagh unit is located in the Northeastern edge of Tarim Block and is considered as the southeast branch of Tianshan mountains (Gao et al. 1980). A complete Neoproterozoic succession is distributed in the study area, containing four sets of glaciation sedimentary strata, referred to as Bayisi, Altungol, Tereeken, and Hankalchough Formations (Xu et al. 2009; Gao et al. 2010). They are correlated to Kiagas, Sturtian, Marinoan, and Gaskier Formations (Macdonald et al. 2010a, b; Gao and Chen 2003; Hoffman and Li 2009), respectively, based on the U-Pb zircon age of volcanic units in these formations.

In this study, the Altungol cap dolostone samples were collected from the southern Yaerdany Mountains I section (the YI section, $40.74^{\circ} \mathrm{N}, 88.94^{\circ} \mathrm{E}$ ), which is located in the southeastern of Quruqtagh area (Fig. 1). Neoproterozoic strata of the YI section are described as the Quruqtagh Group (Gao et al. 1984, 1993) and can be divided into the Bayisi, Altungol, Tereeken, Zhamoketi, Yukkengol, Shuiquan, and Hankalchough Formations. The Altungol Formation unconformably overlies the Bayisi Formation and is conformably overlain by Tereeken Formation. The Zhaobishan Formation, which is reported in the other sections (such as Xishankou section and Yukengou section) (Shen et al. 2008; Xu et al. 2009), is missing in the Yaerdany area. In the YI section, the Altungol Formation consists of a $\sim 45$-m-thick tillite, a $\sim 5-\mathrm{m}$ cap dolostone, and a 20 -m shale. The Altungol cap dolostone consists of dark-gray medium-bedded dolomite with less sedimentary structure. The contact between the dolomite and the underlying tillite is uneven, with the $\sim 10$-cm-thick black shale. The dolomite is conformably overlain by greyweathered shale, in the YI section.

A volcanic unit in the topmost Bayisi Formation gave a SHRIMP zircon U-Pb age of $725 \pm 10 \mathrm{Ma}$ (Xu et al. 2009). He et al. (2014) reported U-Pb zircon ages of $655.9 \pm 4.4$ and $654 \pm 10 \mathrm{Ma}$ from the upper Altungol Formation in Quruqtagh. Therefore, the age of the Altungol diamictites and cap dolostones is between $725 \pm 10$ and $654 \pm 10 \mathrm{Ma}$, which is probably correlated with the Sturtian glaciations (Rooney et al. 2015).

Ten cap dolostone samples (numbered as YI-12-1 to YI-1210) were collected at $0.5-\mathrm{m}$ interval from the Altungol Formation at the YI section. Special sedimentary structures, caused by the giant wave ripples (Allen and Hoffman 2005), are not present in the Altungol cap dolostones (Fig. 2). These dolostones are also lack for other sedimentary structure. Therefore, it is thought that the Altungol cap dolostones were probably deposited below storm wave base. Photomicrograph of the Altungol cap dolostones shows that the samples are homogeneous dolomicrite and micro-powder crystal dolostones (Fig. 2b). There are no typical clastic particles and biological detritus in thin section.

\section{Methods}

Geochemistry methods for the whole rock and acid-insoluble residua of cap dolostones are reported below, including major and trace elements, as well as carbon, oxygen, and strontium isotopes. All of the samples for geochemistry test are taken from the lithology uniform part conformed by the thin sections.

\section{Carbon and oxygen isotopes}

For $\delta^{13} \mathrm{C}$ and $\delta^{18} \mathrm{O}$ analysis, ten fresh cap dolostone samples were cleaned and crushed into rock powder $\sim 5 \mathrm{mg}$ for tests. Rock powder was allowed to react with concentrated $\mathrm{H}_{3} \mathrm{PO}_{4}$ at 
Fig. 1 a Geographic location of the Tarim Block. b Tectonic location of the study area (within the rectangle) in the Tarim basin. c Geological map of the Yaerdany Mountains area
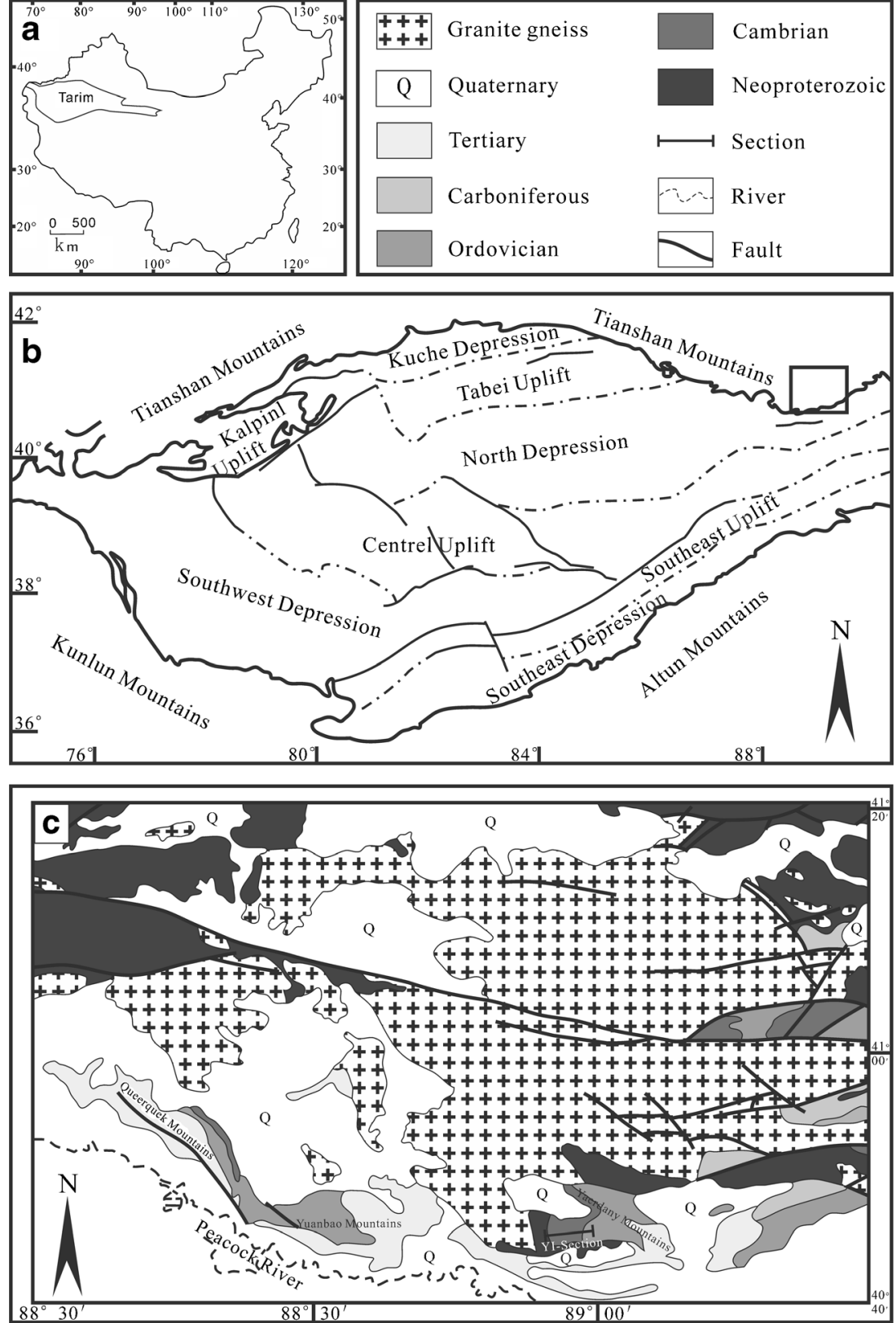

$75^{\circ} \mathrm{C}$ for $3 \mathrm{~h}$, and $\mathrm{CO}_{2}$ was extracted using a traditional offline technique (Craig 1953). The stable isotopic analysis was conducted using a MAT 253 mass spectrometer, at CNNC Beijing Research Institute of Uranium Geology, Beijing, China. The data were expressed as relative isotopic ratios for $\delta^{13} \mathrm{C}$ and $\delta^{18} \mathrm{O}$, in per mil units relative to the VPDB international standard.

\section{Strontium isotopes}

For strontium isotopes tests, nine samples (except YI-12-2) of whole rock were cleaned and crushed into rock powder $\sim 5 \mathrm{mg}$ for tests. Sample powder was digested with a $2.5 \mathrm{M}$ hydrochloric acid and prepared for Sr isotopic analyses (Wang et al. 1988,
2007). The strontium was separated using standard ion exchange techniques (Yang et al. 1997). Sr isotopic analysis was performed on a VG 354 mass spectrometer with five collectors at the Center of Modern Analysis, Nanjing University. Accuracy of Sr isotope was checked by running the Standard Reference Material NBS 987 (certified value $0.710340 \pm 0.000260$ ) with a mean ${ }^{87} \mathrm{Sr} /{ }^{86} \mathrm{Sr}$ value of $0.710241 \pm 0.000007$.

\section{Geochemistry}

In this research, both whole rock (nine samples, except YI-122) and acid-insoluble residua (nine samples, except YI-12-8) elemental geochemistry analyses were utilized. The preparation of acid-insoluble residua of cap dolostones is described as 

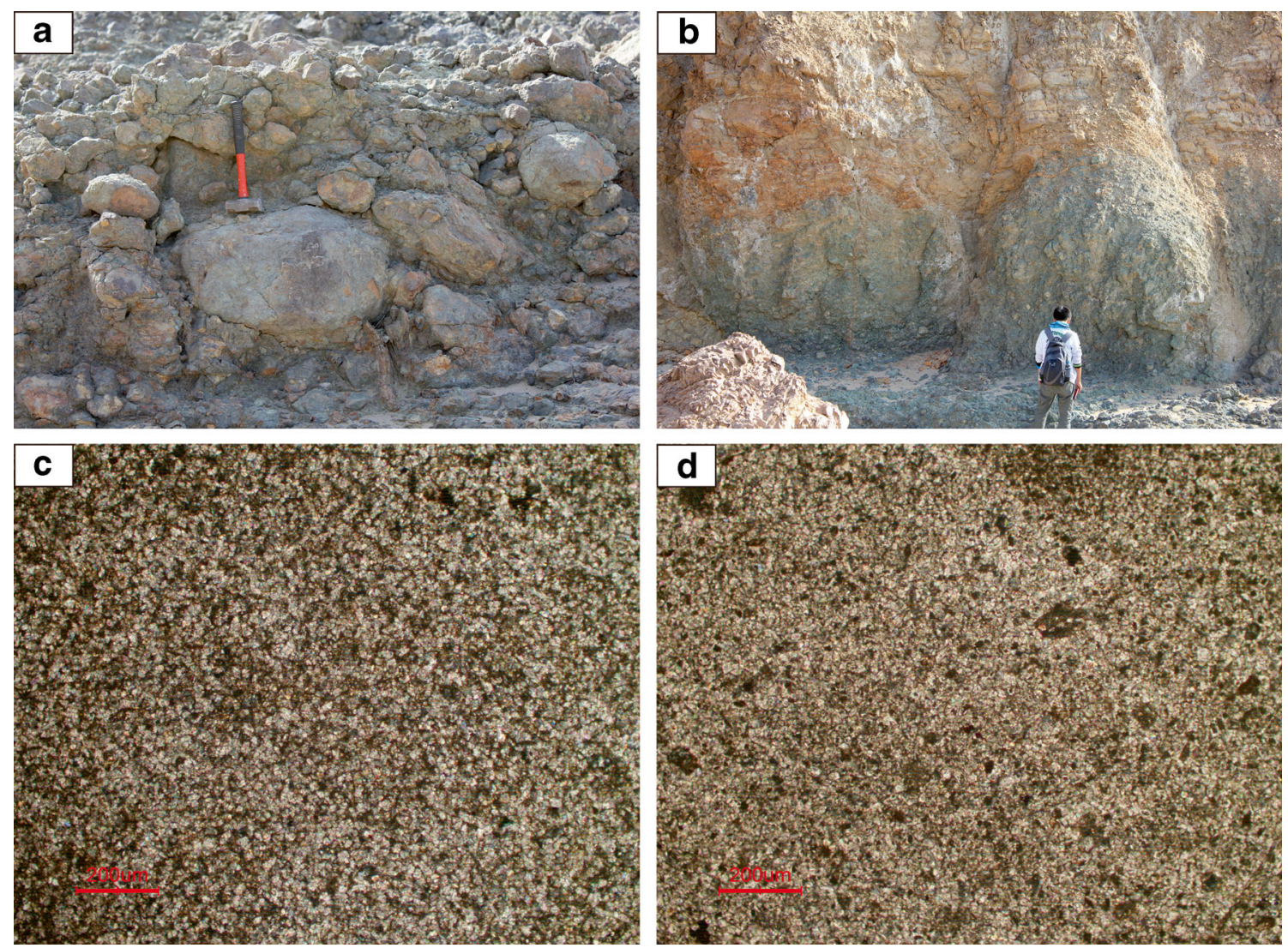

Fig. 2 a Field photograph of Altungol tillites. b Field photograph of Altungol tillites and cap dolostones. c, d Typical photomicrograph of the Altungol cap dolostones

follows. The pure powdered samples were put into $1 \mathrm{~mol} / \mathrm{L}$ hydrochloric acid. When the carbonate part was completely dissolved, the insoluble parts were extracted and cleaned (Wang et al. 1999).

For major element analysis, the sample powder and lithium metaborate flux were mixed in a 1:10 ratio and fused at $1050{ }^{\circ} \mathrm{C}$ in a $\mathrm{Pt}-\mathrm{Au}$ crucible. The resultant melt was cooled, and a glass disk was made for XRF analysis. For trace element and rare earth element (REE) analysis, about $25-\mathrm{mg}$ sample powder was dissolved using a hydrofluoric acid (HF) $+\mathrm{HNO}_{3}$ mixtures in a Teflon bomb at $\sim 80{ }^{\circ} \mathrm{C}$ for $24 \mathrm{~h}$ and then evaporated. When the solutions were evaporated to nearly dry, $1.5 \mathrm{ml} \mathrm{HNO}_{3}, 1.5 \mathrm{ml} \mathrm{HF}$, and $0.5 \mathrm{ml} \mathrm{HClO}_{4}$ were respectively added, and the beakers with solutions were capped for digestion within a high-temperature oven at $180{ }^{\circ} \mathrm{C}$ for at least $48 \mathrm{~h}$ until the samples were completely dissolved. Finally, the solutions were diluted with $1 \% \mathrm{HNO}_{3}$ to $50 \mathrm{ml}$ for determination. The major and trace elements were detected at CNNC Beijing Research Institute of Uranium Geology, Beijing, China. The samples for major element test were analyzed using the Axios MAX X-ray Fluorescence Spectrometer. The trace and rare earth elements were analyzed using the ELEMENT XR plasma mass spectrometer.

\section{Results}

\section{Carbon, oxygen, and strontium isotopes}

The carbon and oxygen isotopic data are presented in Table 1. The negative $\delta^{13} \mathrm{C}_{\mathrm{PDB}}$ values of post-Sturtian cap dolostone have been reported in many carbonate sections over the world. Such as the $\delta^{13} \mathrm{C}_{\mathrm{PDB}}$ average value of the Rasthof Formation in Namibian is $-2.39 \%$ (Hurtgen et al. 2002), and two sections of the Sturtian Formation in South Australia show that the average value of $\delta^{13} \mathrm{C}_{\text {PDB }}$ is $-1.77 \%$ of dolostone (Giddings and Wallace 2009). In the study area, Kou et al. (2008) reported values of $\delta^{13} \mathrm{C}_{\mathrm{PDB}}$ ranging from -2.09 to $-2.43 \%$. In the YI section, the values of $\delta^{13} \mathrm{C}_{\mathrm{PDB}}$ begin at $-2.5 \%$ and increase to $-1 \%$. The overall $\delta^{13} \mathrm{C}_{\mathrm{PDB}}$ is increasing from bottom to top but drops abruptly to -4 and $-2.2 \%$ at 2 and $4 \mathrm{~m}$ (Fig. 3). The $\delta^{18} \mathrm{O}_{\mathrm{PDB}}$ values range from -8.1 to $-4.3 \%$. The Strontium isotope compositions vary between 0.709125 and 0.709608 , with an average error of \pm 0.000007 (Table 1 and Fig. 4c).

\section{Elemental geochemistry}

In this study, the elemental data of the cap dolostones acidinsoluble part were obtained (Tables 2, 3, 4, and 5). Huang and 
Table 1 Isotopic data and $\mathrm{Fe}, \mathrm{Mn}$, and $\mathrm{Sr}$ comments of the Altungol cap carbonate at the YI section

\begin{tabular}{lllllllll}
\hline Number & Height $(\mathrm{m})$ & $\delta^{13} \mathrm{C}_{\mathrm{PDB}}(\%)$ & $\delta^{18} \mathrm{O}_{\mathrm{PDB}}(\% o)$ & ${ }^{87} \mathrm{Sr} /{ }^{86} \mathrm{Sr}$ & Error & $\mathrm{Fe}(\mathrm{ppm})$ & $\mathrm{Mn}(\mathrm{ppm})$ & $\mathrm{Sr}(\mathrm{ppm})$ \\
\hline YI-12-1 & 0.5 & -2.5 & -4.6 & 0.709125 & 0.000009 & 36,983 & 1394 \\
YI-12-2 & 1.0 & -1.8 & -4.3 & ns. & ns. & ns. & ns. \\
YI-12-3 & 1.5 & -2.5 & -4.9 & 0.709167 & 0.000007 & 63,451 & 3207 & ns. \\
YI-12-4 & 2.0 & -4 & -4.8 & 0.709203 & 0.000008 & 44,357 & 2254 \\
YI-12-5 & 2.5 & -1.1 & -4.9 & 0.709239 & 0.000009 & 50,820 & 2696 \\
YI-12-6 & 3.0 & -0.6 & -4.5 & 0.709347 & 0.000010 & 78,174 & 3773 \\
YI-12-7 & 3.5 & -0.5 & -7.8 & 0.709452 & 0.000008 & 64,556 & 3246 \\
YI-12-8 & 4.0 & -2.2 & -7.4 & 0.709515 & 0.000006 & 74,324 & 3780 & 91.8 \\
YI-12-9 & 4.5 & -0.6 & -8.1 & 0.709546 & 0.000009 & 87,562 & 4803 \\
YI-12-10 & 5.0 & -1 & -7.9 & 0.709608 & 0.000007 & 75,001 & 3881 \\
\hline
\end{tabular}

$n s$. no sufficient yield

Fig. 3 Lithology of the southern Yaerdany Mountains I section and stable isotope data of cap dolostones

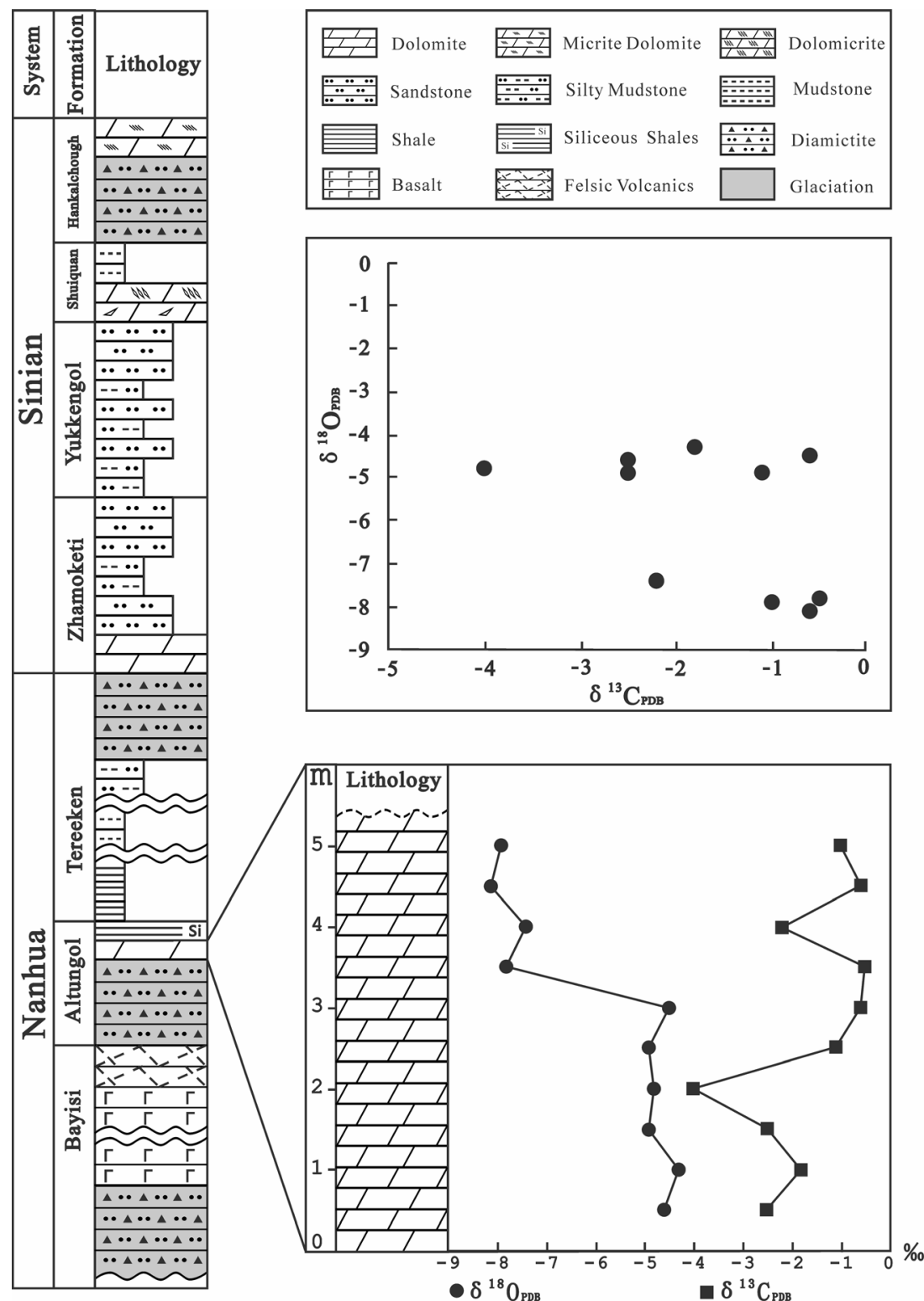


Bausch (1999) indicated that most of the acid-insoluble residua in the carbonates are related to the terrigenous deposits. It is inferred that the composition of the acidinsoluble residua depends on the source and the corresponding alterations, like chemical weathering. Thus, the geochemical indicators of clastic rock (especially the mudstone) can be used to analyze acid-insoluble residua of cap dolostone, to reflect the environment changes of the source region.

The major element geochemistry results of the whole rock are presented in Table 2. The Altungol cap dolostones have relatively high content of $\mathrm{SiO}_{2}$ and $\mathrm{Al}_{2} \mathrm{O}_{3}$, which range from 2.27 to $5.67 \%$ and 0.416 to $1.32 \%$. The $\mathrm{Mg} / \mathrm{Ca}$ $(\mathrm{mol} / \mathrm{mol})$ ratios of most samples range from 0.768 to 0.829 (except the ratio of YI-12-3 which is 0.486 ). The iron content (wt\%) maintains at a high level and increases from 5.15 to $10.21 \%$ (Fig. 4e).

In the acid-insoluble part (Table 3), the ratios of $\mathrm{Ni} /$ $\mathrm{Ti}, \mathrm{Zn} / \mathrm{Ti}, \mathrm{Y} / \mathrm{Ti}, \mathrm{Cu} / \mathrm{Ti}$, and $\mathrm{Zn} / \mathrm{Y}$ are relatively high in the lower part of the section and decrease upward (Fig. $4 a, b$ ). These ratios have an obvious variation at $3 \mathrm{~m}$, which possess the analogous change trend with $\delta^{13} \mathrm{C}_{\mathrm{PDB}}$. The samples below $1.5 \mathrm{~m}$ show an iron enrichment in acid-insoluble residua (Fig. 4d).

The REE data of the Altungol cap dolostones, NASCnormalized REE patterns, and parameters (Haskin and Frey 1966) are presented in Table 4 and Fig. 5. The total REE contents of most samples range from 12.4 to 79.6 (except the value of YI-12-1 is 218). As various barium compounds can cause artificial positive Eu anomalies when measured by ICP-MS (Dulski 1994), the extremely high Ba concentration may result in the positive Eu anomaly of YI-12-10. The samples of the Altungol cap dolostone are characterized by LREE depletion relative to HREE $\left(\mathrm{La}_{\mathrm{N}} / \mathrm{Yb}_{\mathrm{N}}=0.124-0.671\right.$, except YI-12-1 La $\left.\mathrm{L}_{\mathrm{N}} / \mathrm{Yb}_{\mathrm{N}}=4.86\right)$, no $\mathrm{Ce}$ anomalies $(\mathrm{Ce} / \mathrm{Ce} *$ ranges from 0.72 to 1.35$)$, and negative $\mathrm{Eu}$ anomalies $\left(\mathrm{Eu} / \mathrm{Eu}^{*}\right.$ ranges from 0.163 to 0.935 , except YI-12-10 Eu/Eu* $=2.03$ ).

\section{Discussion}

\section{Reliability of geochemical data}

As the cap carbonates are significantly enriched in $\mathrm{Mn}$ and Fe, presumably originating from weathering products (Shen et al. 2005), ratios of $\mathrm{Mn} / \mathrm{Sr}$ were not measured to evaluate diagenesis. Theoretically, $\mathrm{Ca}$ and $\mathrm{Mg}$ contents of sedimentary dolostone are the stoichiometric composition $(\mathrm{CaO}=30.4 \%, \mathrm{MgO}=21.7 \%)$ (Warren 2000). Actually, natural dolostone shows lower content of $\mathrm{MgO}$ and $\mathrm{CaO}$ and constant $\mathrm{Mg} / \mathrm{Ca}$ ratios (Chen et al. 2010). However, through dolomitizing diagenesis on sedimentary limestones, $\mathrm{Mg}^{2+}$ will substitute $\mathrm{Ca}^{2+}$ in crystals and $\mathrm{CaO}$ and $\mathrm{MgO}$ will show a negative linear relationship. Zhao et al. (2012) suggested that theoretical sedimentary dolomites precipitate with different comments of $\mathrm{CaO}$ and $\mathrm{MgO}$ but constant $\mathrm{Mg} / \mathrm{Ca}$ ratios (the line of sedimentation). Actually, in the sedimentary environment with low $\mathrm{Mg}(\mathrm{Mg} / \mathrm{CaO}<1)$, the comments of $\mathrm{CaO}$ and $\mathrm{MgO}$ of natural sedimentary dolomites show a positive relationship (the lines parallel to the sedimentation line). In this research, the $\mathrm{CaO}$ and $\mathrm{MgO}$ contents of the cap dolostone samples show a positive linear relationship (except one sample), while the line of $\mathrm{MgO} / \mathrm{CaO}$ is parallel to the line of sedimentation (Fig. 6). Thus, the $\mathrm{CaO}$ and $\mathrm{MgO}$ contents of the cap dolostone samples indicate a sedimentary origin of the cap dolostones (Zhao et al. 2012). In addition, $\delta^{13} \mathrm{C}_{\mathrm{PDB}}$ has no linear relationship with $\delta^{18} \mathrm{O}_{\mathrm{PDB}}$, which indicates that the samples have not been influenced by strong diagenesis and hydrothermal alteration, and the $\delta^{13} \mathrm{C}_{\mathrm{PDB}}$ compositions reflect depositional conditions (Derry et al. 1994).

REEs of the marine carbonates reflect the geochemistry of waters in which the carbonates were deposited (Webb and Kamber 2000; Nothdurft et al. 2004), and they are immobile during diagenesis (Webb et al. 2009). However, diagenetic exchange after deposition would also cause Ce-enriched, Eu-depleted, and low $\mathrm{Dy}_{\mathrm{N}} / \mathrm{Sm}_{\mathrm{N}}$ ratios (Shields and Stille 2001).

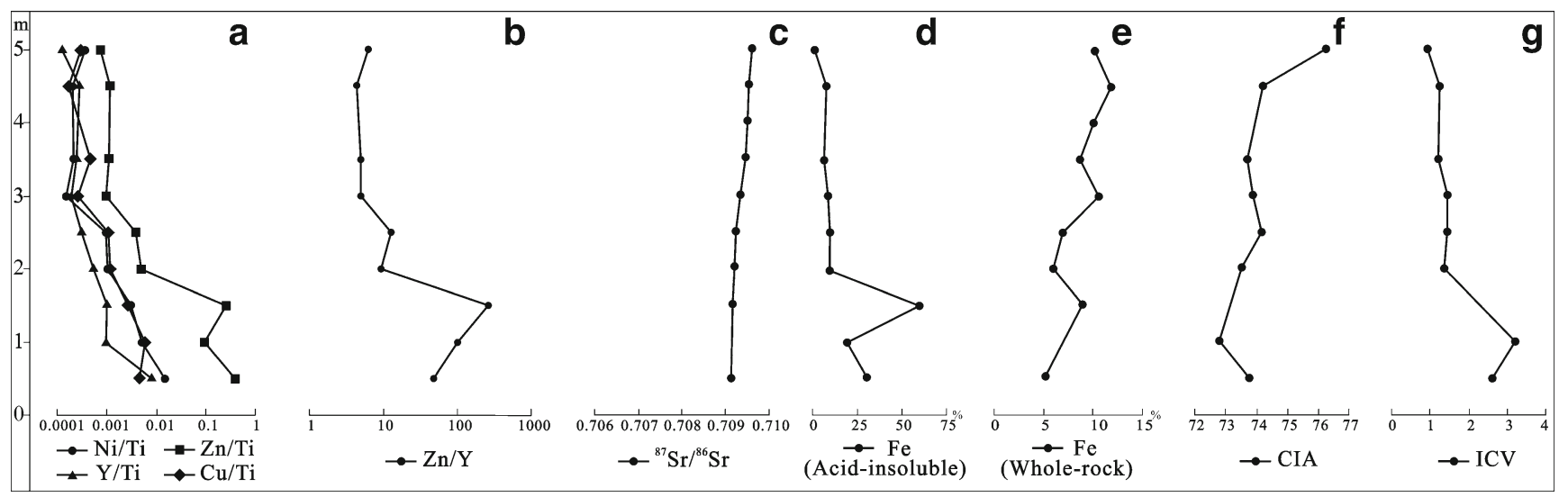

Fig. 4 Geochemical data of the Altungol cap dolostones. a Ratios of $\mathrm{Cu} /$ $\mathrm{Ti}, \mathrm{Ni} / \mathrm{Ti}, \mathrm{Zn} / \mathrm{Ti}$, and $\mathrm{Y} / \mathrm{Ti}$ for acid-insoluble residua. b Ratio of $\mathrm{Zn} / \mathrm{Y}$ for acid-insoluble residua. c Ratio of whole-rock ${ }^{87} \mathrm{Sr} /{ }^{86} \mathrm{Sr}$. d Iron content of acid-insoluble residua. e Iron content of whole rock. $\mathbf{f}$ Chemical index of alteration (CIA). $\mathbf{g}$ Index of chemical variation (ICV) 
Thus, if the REE of carbonates samples has been changed by diagenetic exchange, the $\mathrm{Ce} / \mathrm{Ce}^{*}$ and $\mathrm{Eu} / \mathrm{Eu}^{*}$ will show a negative correlation relationship, while the $\mathrm{Ce} / \mathrm{Ce} e^{*}$ and $\mathrm{Dy}_{\mathrm{N}} / \mathrm{Sm}_{\mathrm{N}}$ will show the same relationship. In the YI section, there are no negative correlations of $\mathrm{Ce} / \mathrm{Ce}{ }^{*}-\mathrm{Eu} / \mathrm{Eu}^{*}$ and $\mathrm{Ce} / \mathrm{Ce}{ }^{*}-\mathrm{Dy}_{\mathrm{N}} / \mathrm{Sm}_{\mathrm{N}}$ caused by diagenetic alteration (Figs. $7 \mathrm{a}, \mathrm{b}$ ), suggesting that the REE of the samples can represent the primary seawater and the geochemical data have not been changed after deposition $(\mathrm{Ce} /$ $\left.\mathrm{Ce}^{*}=2 * \mathrm{Ce}_{\mathrm{N}} /\left(\mathrm{La}_{\mathrm{N}}+\mathrm{Pr}_{\mathrm{N}}\right), \mathrm{Eu} / \mathrm{Eu}^{*}=2 * \mathrm{Eu}_{\mathrm{N}} /\left(\mathrm{Sm}_{\mathrm{N}}+\mathrm{Gd}_{\mathrm{N}}\right)\right)$. The values of $\mathrm{Eu}$ and $\mathrm{Ca}$ (except YI-12-3) show a positive correlation, suggesting that the $\mathrm{Eu}$ anomalies may be caused by sedimentary environment (Fig. 7c). The La anomalies can influence the $\mathrm{Ce}$ anomaly data and must be removed by using $\operatorname{Pr} / \mathrm{Pr}^{*}$ values (Bau and Dulski 1999), before using the $\mathrm{Ce} / \mathrm{Ce}^{*}$ data. According to the binary diagram of the relationship between $\mathrm{Ce} / \mathrm{Ce}^{*}$ and $\operatorname{Pr} / \operatorname{Pr} *\left(\operatorname{Pr} / \operatorname{Pr}^{*}=\operatorname{Pr}_{\mathrm{N}} /\left(0.5 \mathrm{Ce}_{\mathrm{N}}+0.5 \mathrm{Nd}_{\mathrm{N}}\right)\right)$, the $\mathrm{Ce}$ anomalies can be divided into five fields (Fig. 7d): field A, neither $\mathrm{Ce}$ nor La anomaly; field $\mathrm{B}$, positive $\mathrm{La}$ anomaly and no $\mathrm{Ce}$ anomaly; field $\mathrm{C}$, negative $\mathrm{La}$ anomaly and no Ce anomaly; field $\mathrm{D}$, true positive $\mathrm{Ce}$ anomaly; and field E, true negative Ce anomaly. Figure $7 \mathrm{~d}$ shows that the samples above $3 \mathrm{~m}$ show true positive Ce anomaly.

Trace element criteria for assessing optimal strontium isotope of carbonate samples have been proposed for the Precambrian (Brand and Veizer 1980; Derry et al. 1989; Asmerom et al. 1991; Kaufman et al. 1993). Generally, samples with low $\mathrm{Sr}$ contents and high $\mathrm{Fe} / \mathrm{Sr}$ or $\mathrm{Mn} / \mathrm{Sr}$ are least likely to preserve the original marine ${ }^{87} \mathrm{Sr} /{ }^{86} \mathrm{Sr}$ (Miller et al. 2003). However, the cap carbonates have the characteristics of significantly high in $\mathrm{Mn}$ and Fe contents (Shen et al. 2005). The ${ }^{87} \mathrm{Sr} /{ }^{86} \mathrm{Sr}$ ratios are higher than 0.709 , which is much greater than the $\mathrm{Sr}$ isotope of $\sim 0.707$ or less for the Sturtianaged cap dolostones (Halverson et al. 2007), suggesting that the $87 \mathrm{Sr} / 86 \mathrm{Sr}$ values do not represent the $\mathrm{Sr}$ isotope compositions of pristine meltwater and/or ocean water after the Sturtian glaciation but altered signals.

\section{Changes of the ocean chemical stratification}

In the YI section, the $\delta^{13} \mathrm{C}_{\mathrm{PDB}}$ values of cap dolostones display a distinct depletion from bottom to top and the $\mathrm{Zn} / \mathrm{Y}$ of the acid-insoluble residua presents relatively high ratios from 0.5 to $1.5 \mathrm{~m}$. The values of zinc and ytterbium usually display a correlation during weathering (Nesbitt and Markovics 1997). However, the ratios of $\mathrm{Zn} / \mathrm{Y}$ in the acid-insoluble residua are $46.99,98.53$, and 262.53 at $0.5,1$, and $1.5 \mathrm{~m}$, respectively, then drop to 9.39 at $2 \mathrm{~m}$, and keep stable above $2 \mathrm{~m}$ with an average value of 7 (Fig. 4b). Nesbitt and Markovics (1997) found that the ratios of $\mathrm{Cu} / \mathrm{Ti}, \mathrm{Ni} / \mathrm{Ti}, \mathrm{Zn} / \mathrm{Ti}$, and $\mathrm{Y} / \mathrm{Ti}$ always show similar variation during weathering. These ratios presented glacial/interglacial cycles together in the sediments of the South China Sea (Wei et al. 2004; Liu et al. 2012). The ratios are higher during interglacials and lower during glacials. In this section, these ratios in the acid-insoluble residua are high at the bottom but low at the top, while the $\mathrm{Zn} / \mathrm{Ti}$ ratios and their decrease are different from the others (Fig. 4a). As $\mathrm{Cu}, \mathrm{Ni}, \mathrm{Zn}$, and $\mathrm{Y}$ have similar values in the upper continental crust (Taylor and McLennan 1995), the significant difference of $\mathrm{Zn} / \mathrm{Ti}$ could be inferred that zinc has a second source while $\mathrm{Cu}, \mathrm{Ni}$, and Y do not have. Kuss and Kremling (1999) considered that the excess fluxes of $\mathrm{Cu}, \mathrm{Ni}$, and $\mathrm{Zn}$ are linearly related to organic carbon in the northeast Atlantic sediments (Kuss and Kremling 1999). Especially, Zn is an important element in organisms and an essential element constituting kinds of enzymes (Anderson et al. 1978). For example, in algae, the contents of $\mathrm{Cu}, \mathrm{Ni}$, and $\mathrm{Y}$ are similar, but the content of $\mathrm{Zn}$ is about ten times of their (Guo et al. 2003; Xie et al. 2003). In the model of the ocean stratification, the deep water was enriched with organics during glacials (Shen et al. 2005,

Table 2 Major (\%) and trace (ppm) element data of the Altungol cap dolostone at the YI section

\begin{tabular}{|c|c|c|c|c|c|c|c|c|c|c|c|c|c|c|c|c|c|}
\hline Number & Height (m) & $\mathrm{SiO}_{2}$ & $\mathrm{Al}_{2} \mathrm{O}_{3}$ & $\mathrm{Fe}_{2} \mathrm{O}_{3}$ & $\mathrm{FeO}$ & $\mathrm{MgO}$ & $\mathrm{CaO}$ & $\mathrm{Na}_{2} \mathrm{O}$ & $\mathrm{K}_{2} \mathrm{O}$ & $\mathrm{MnO}$ & $\mathrm{TiO}_{2}$ & $\mathrm{P}_{2} \mathrm{O}_{5}$ & LOI & Total & $\mathrm{Ba}$ & $\mathrm{Sr}$ & $\begin{array}{l}\mathrm{Mg} / \mathrm{Ca} \\
(\mathrm{mol} / \mathrm{mol})\end{array}$ \\
\hline YI-12-1 & 0.5 & 5.61 & 1.32 & 3.95 & 1.2 & 16.8 & 28.38 & 0.055 & 0.399 & 0.18 & 0.075 & 0.063 & 42.59 & 99.95 & 247 & 166 & 0.829 \\
\hline YI-12-2 & 1.0 & ns. & ns. & ns. & ns. & ns. & ns. & ns. & ns. & ns. & ns. & ns. & ns. & ns. & ns. & ns. & ns. \\
\hline YI-12-3 & 1.5 & 3.55 & 0.416 & 8.52 & 0.49 & 11.61 & 33.42 & 0.083 & 0.107 & 0.414 & 0.031 & 0.034 & 41.22 & 94.8 & 213 & 176 & 0.486 \\
\hline YI-12-4 & 2.0 & 2.27 & 0.588 & 3.47 & 2.58 & 17.84 & 30.18 & 0.057 & 0.173 & 0.291 & 0.051 & 0.442 & 44.08 & 100 & 226 & 119 & 0.828 \\
\hline YI-12-5 & 2.5 & 3.57 & 0.732 & 4.36 & 2.61 & 16.92 & 28.57 & 0.466 & 0.226 & 0.348 & 0.054 & 0.159 & 43.99 & 99.23 & 612 & 91.8 & 0.829 \\
\hline YI-12-6 & 3.0 & 4.21 & 0.73 & 6.09 & 4.57 & 15.62 & 28.49 & 0.127 & 0.198 & 0.487 & 0.039 & 0.129 & 43.31 & 99.8 & 826 & 202 & 0.768 \\
\hline YI-12-7 & 3.5 & 3.47 & 0.663 & 4.9 & 3.89 & 16.97 & 28.82 & 0.023 & 0.191 & 0.419 & 0.045 & 0.036 & 43.92 & 98.13 & 531 & 98.5 & 0.824 \\
\hline YI-12-8 & 4.0 & 4.53 & 0.678 & 5.74 & 4.39 & 16.27 & 28.16 & 0.093 & 0.187 & 0.488 & 0.042 & 0.065 & 43.14 & 98.87 & 616 & 84.6 & 0.809 \\
\hline YI-12-9 & 4.5 & 3.17 & 0.621 & 6.72 & 5.21 & 15.75 & 28.43 & 0.042 & 0.176 & 0.62 & 0.039 & 0.026 & 43.82 & 100.6 & 268 & 96.3 & 0.776 \\
\hline YI-12-10 & 5.0 & 3.14 & 0.567 & 5.67 & 4.54 & 16.52 & 28.92 & 0.036 & 0.159 & 0.501 & 0.041 & 0.116 & 43.77 & 100.4 & 2237 & 127 & 0.800 \\
\hline
\end{tabular}

$n s$. no sufficient yield 


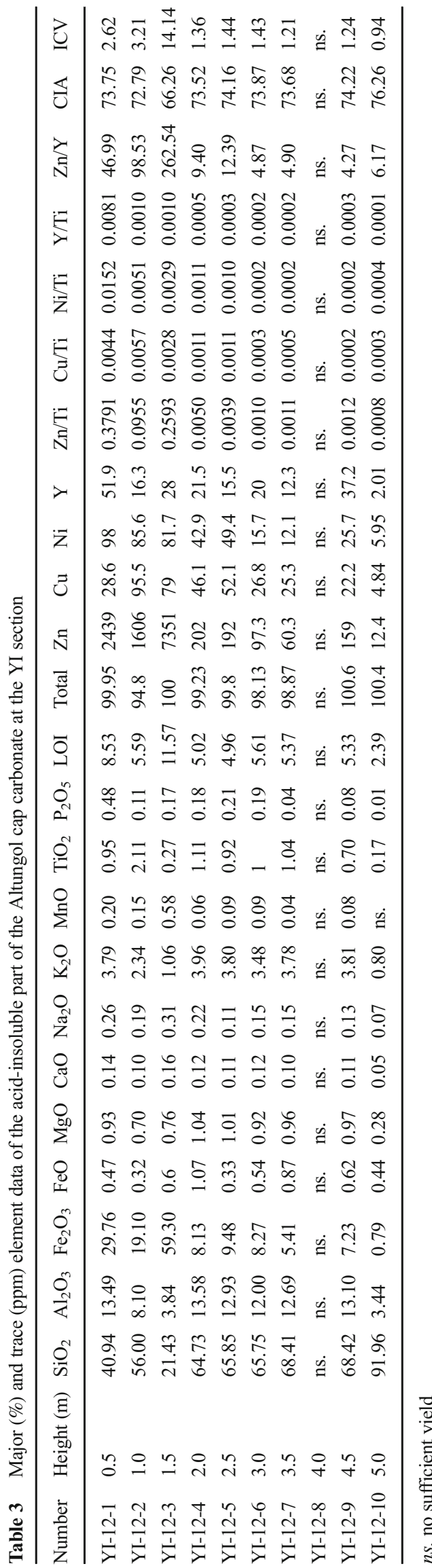

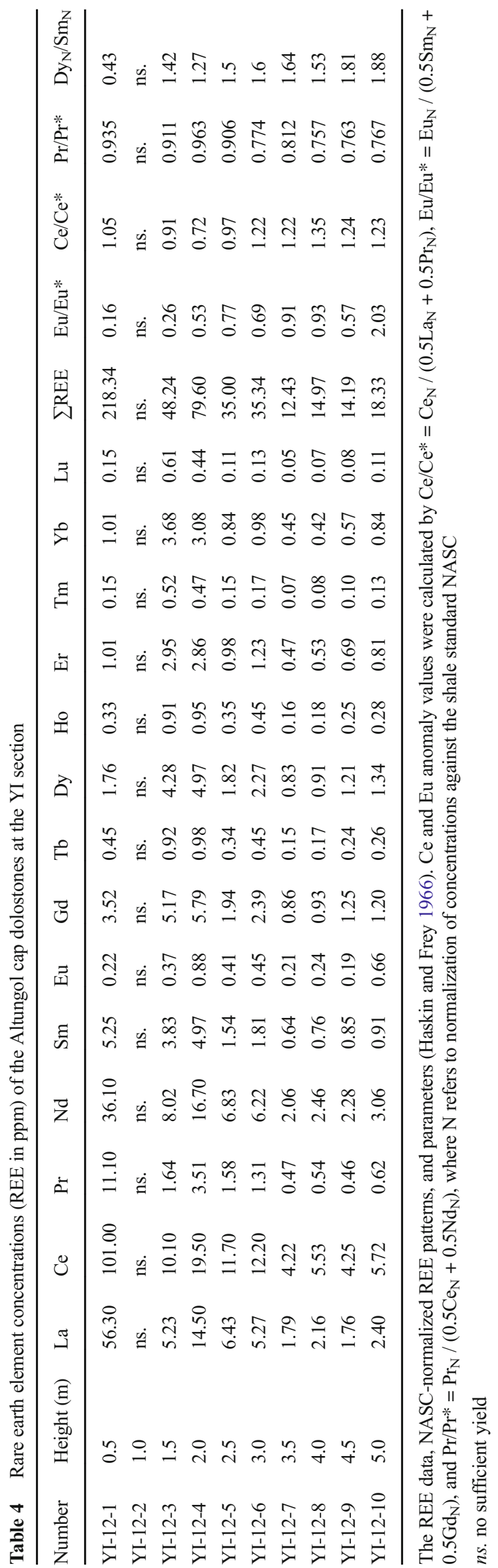




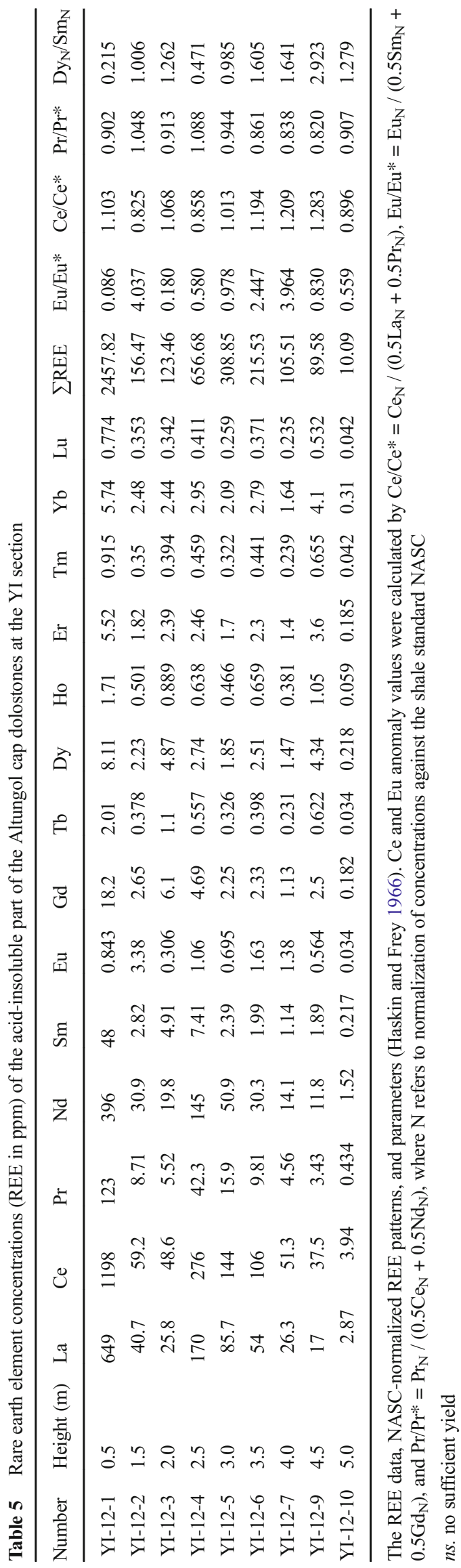

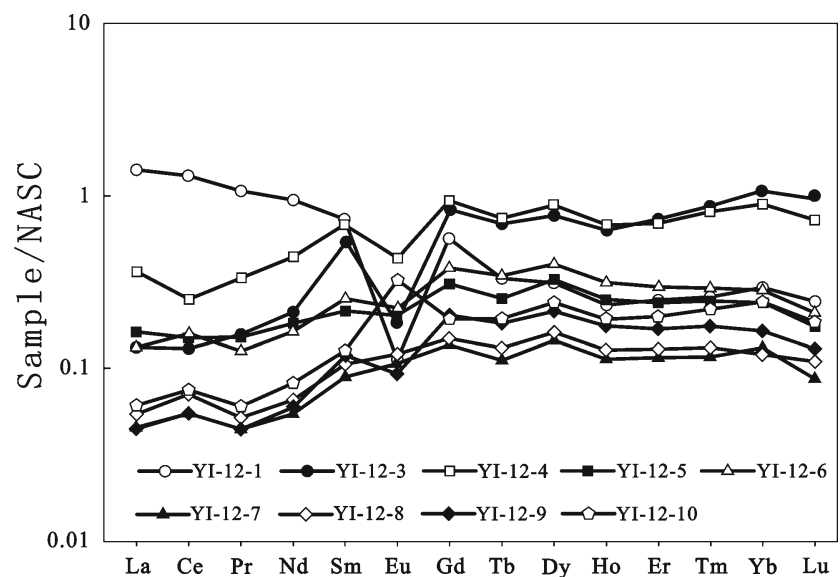

Fig. 5 NASC-normalized REE distribution patterns for the Altungol cap dolostones

2008, 2010; Giddings and Wallace 2009). Therefore, the enrichment of zinc in the acid-insoluble residua is perhaps related to the organic-enriched deep water. The organic-enriched deep water is likely to be the second source of $\mathrm{Zn}$ in the acidinsoluble residua.

The $\delta^{13} \mathrm{C}$ negative shift in Sturtian cap dolostones is a global event and is also reported in Australia and Namibia (Hurtgen et al. 2002; Giddings and Wallace 2009). During Sturtian glaciation, the presence of large ice sheet isolated the air and seawater and built up the anoxic, alkaline, and organic-enriched deep water. When the snowball earth unfroze, a large number of freshwater flowed into the sea. The stratification of seawater was destroyed by cold freshwater and upwelling deep water, and organic carbon was oxidized (Giddings and Wallace 2009). The stratified and mixed states in the post-glacial ocean were also reported in Marinoan cap carbonates (Halverson et al. 2005, 2006). Therefore, we suggest the Altungol cap dolostones were deposited from the water which was rich in organic carbon. The cap dolostones which formed earlier show more negative $\delta^{13} \mathrm{C}_{\mathrm{PDB}}$ and higher ratios of $\mathrm{Zn} / \mathrm{Y}$ and $\mathrm{Zn} / \mathrm{Ti}$ of the acid-insoluble residua. As the organics had been consumed,

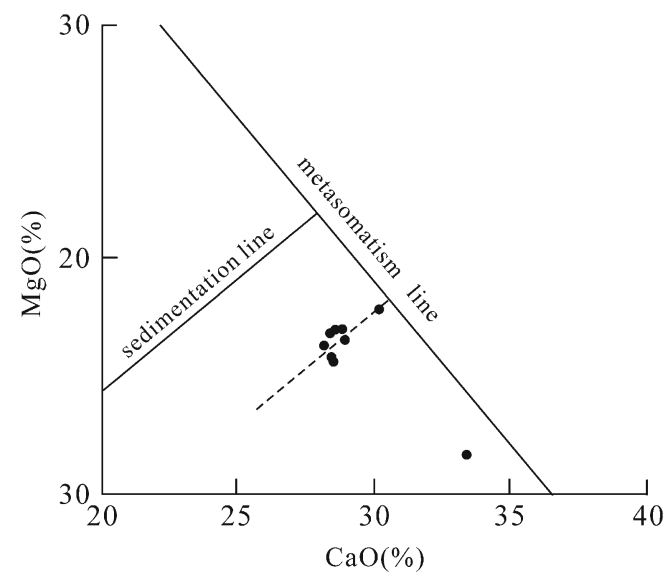

Fig. 6 Cross-plot of $\mathrm{MgO}$ and $\mathrm{CaO}$ (the sedimentation line and metasomatism line were calculated from Zhao et al. [2012]) 
Fig. 7 a Cross-plots of $\mathrm{Ce} / \mathrm{Ce}^{*}$ $\mathrm{Eu} / \mathrm{Eu}^{*}$. b Cross-plots of $\mathrm{Ce} / \mathrm{Ce}^{*}$ $\mathrm{Dy}_{\mathrm{N}} / \mathrm{Sm}_{\mathrm{N}}$. $\mathbf{c}$ Cross-plots of CaEu. d Cross-plots of $\mathrm{Ce} / \mathrm{Ce}^{*}-\mathrm{Pr} /$ Pr*. Field $A$, neither Ce nor La anomaly; field $B$, positive La anomaly and no Ce anomaly; field $C$, negative $\mathrm{La}$ anomaly and no Ce anomaly; field $D$, true positive Ce anomaly; and field $E$, true negative $\mathrm{Ce}$ anomaly
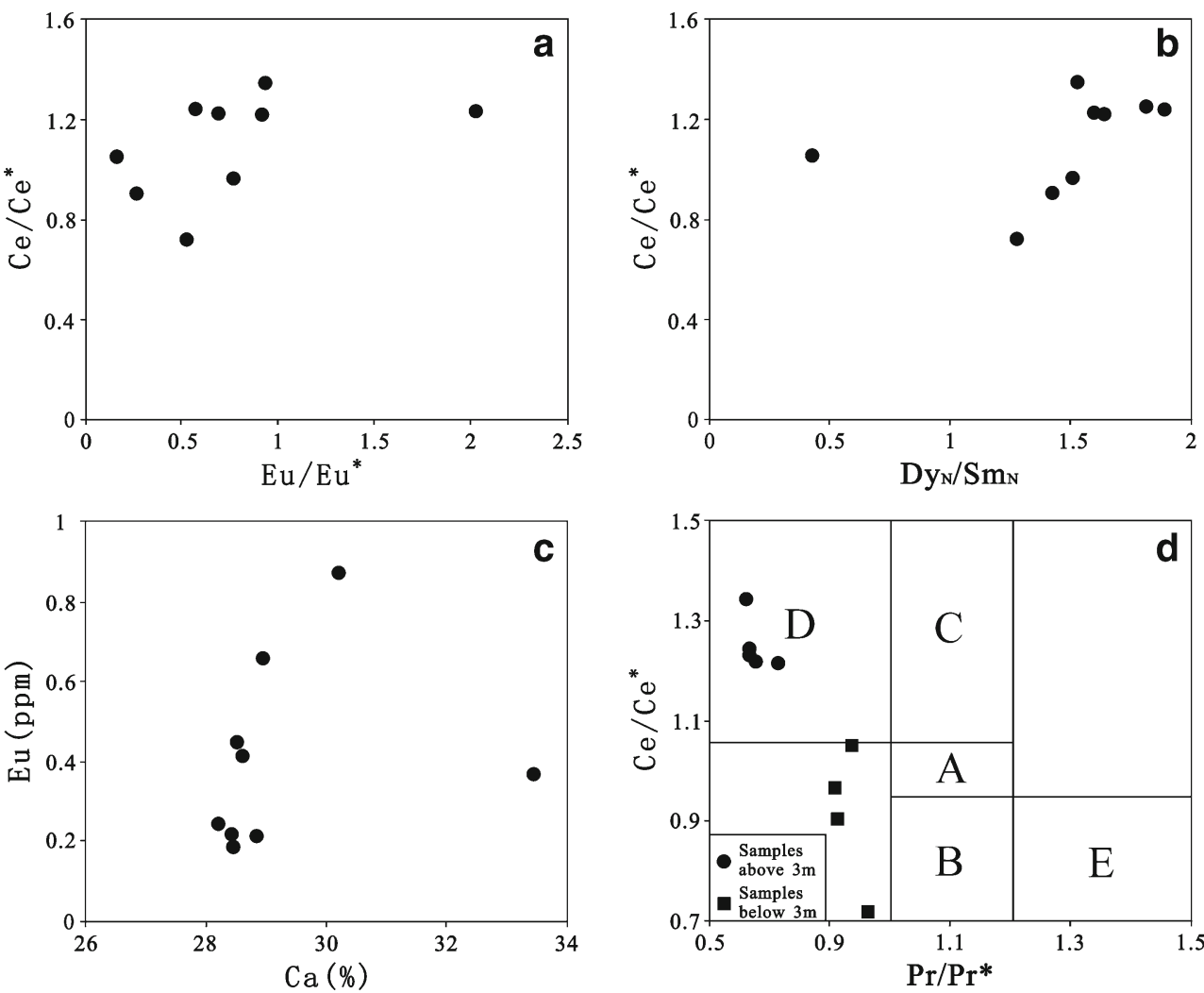

the $\delta^{13} \mathrm{C}_{\mathrm{PDB}}$ was rising, but the ratios of $\mathrm{Zn} / \mathrm{Y}$ and $\mathrm{Zn} / \mathrm{Ti}$ of the acid-insoluble residua were declining.

The Eu/Eu* data of whole rock shows negative anomaly (except YI-12-10), especially in the samples below $2 \mathrm{~m} \mathrm{(Eu/}$ $\left.\mathrm{Eu}^{*}<0.55\right)$. As the $\mathrm{Eu}^{3+} / \mathrm{Eu}^{2+}$ is controlled by oxidation (Kamber and Webb 2001; Bolhar et al. 2004; Frimmel 2009; Zhao and Jones 2013), the negative anomaly $\mathrm{Eu} / \mathrm{Eu} *$ reflects an alkaline and oxic environment. Thus, the strong negative anomaly of Eu below $2 \mathrm{~m}$ may indicate an oxic sedimentary environment, which is probably caused by the oxic melting water. The negative $\mathrm{Eu}$ anomaly diminished in the samples above $2 \mathrm{~m}$, suggesting the weakening of oxidation. In addition, the high $\sum$ REE $(>10)$ and no Ce anomalies of cap dolostones (the samples below $3 \mathrm{~m}$ ) reflect the input of continental silicate detritus (Chen et al. 2015) carried by the meltwater. Alternatively, the samples above $3 \mathrm{~m}$ with the positive Ce anomaly may be due to anoxic condition (Ling et al. 2013). This anoxic condition probably reflects the rising sea levels caused by melting glaciers.

The chemical index of alteration $\left(\mathrm{CIA}=\left[\mathrm{Al}_{2} \mathrm{O}_{3} /\left(\mathrm{Al}_{2} \mathrm{O}_{3}+\right.\right.\right.$ $\left.\left.\left.\mathrm{CaO}+\mathrm{Na}_{2} \mathrm{O}+\mathrm{K}_{2} \mathrm{O}\right)\right] \times 100\right)($ Nesbitt and Young 1982) and chemical variation $\left(\mathrm{ICV}=\left(\mathrm{Fe}_{2} \mathrm{O}_{3}+\mathrm{K}_{2} \mathrm{O}+\mathrm{Na}_{2} \mathrm{O}+\mathrm{CaO}+\right.\right.$ $\left.\left.\mathrm{MgO}+\mathrm{MnO}+\mathrm{TiO}_{2}\right) / \mathrm{Al}_{2} \mathrm{O}_{3}\right)(\mathrm{Cox}$ et al. 1995) have been widely used to quantify the degree of chemical weathering and to reconstruct the paleoweathering conditions of terrigenous sediments (Bock et al. 1998; Roddaz et al. 2006; Schoenborn and Fedo 2011; Jian et al. 2013). The values of
CIA increase with chemical weathering enhancement (Nesbitt and Young 1982). The CIA $=50 \sim 65$ means that the environment is dry and cold and chemical weathering is weak. The CIA $=65 \sim 85$ shows that the environment is warm and wet and chemical weathering is medium. The CIA $=85 \sim 100$ means that the environment is hot and humid with strong chemical weathering.

The CIA of the cap dolostones of acid-insoluble residua in this section ranges from 72 to 77 and rises from bottom to top, indicating that the samples are formed from a warm and wet environment and moderate chemical weathering condition (Fig. 4f). The values of ICV drop with chemical weathering enhancement, and 1 is the boundary between strong and weak chemical weathering. (Cox et al. 1995). The ICV value drops from $\sim 3$ at bottom to $\sim 1$ at top (Fig. $4 \mathrm{~g}$ ). Both ICV and CIA show the same trend that chemical weathering increases from bottom to top in the YI section.

\section{Changes of continental climate}

Hoffman and Schrag (2000) suggested that when tropical oceans thawed, evaporated seawater would work along with carbon dioxide to produce a more intense greenhouse. Surface temperatures would soar to more than $50{ }^{\circ} \mathrm{C}$, driving an intense cycle of evaporation and rainfall (Hoffman and Schrag 2000). We consider that the evidence of freshwater can be found in the acid-insoluble residua. As the acid-insoluble 


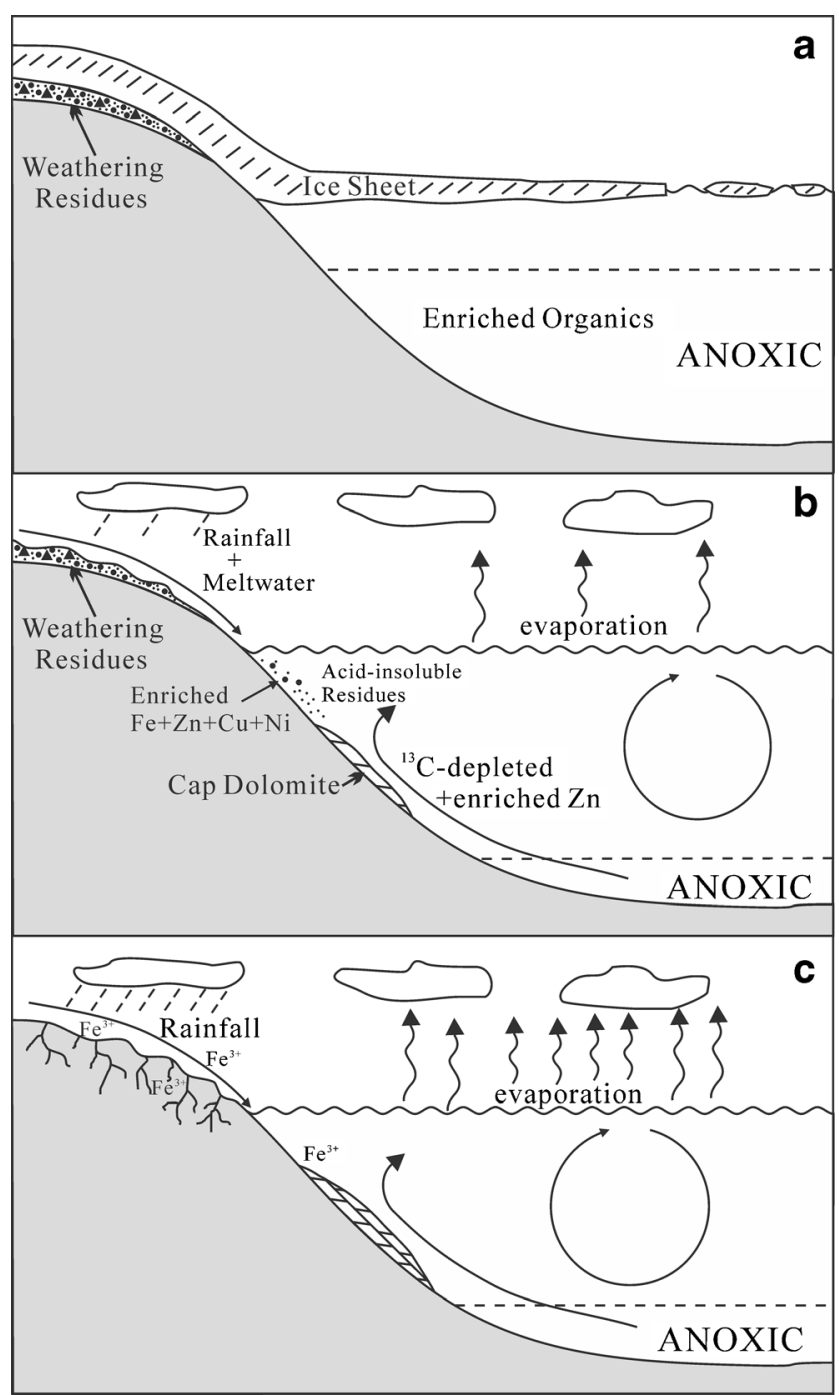

Fig. 8 Environmental change model of post-glacial ocean and continent. a During the Altungol glaciation, the ocean was covered by the ice sheet and the bottom water was anoxic, alkaline, and enriched in organics. b When the Snowball Earth thawed, meltwater destroyed the ocean stratification. Deeper water upwelled and was oxidized, causing the water to be enriched in $\mathrm{Zn}$ and depleted in $\delta^{13} \mathrm{C}$. Weathering residues, enriched in $\mathrm{Fe}, \mathrm{Zn}, \mathrm{Ni}$, and $\mathrm{Cu}$, were carried into the ocean by surface runoff. $\mathbf{c}$ The intense greenhouse drove an intense cycle of evaporation and rainfall. The weathering residues of the parent rocks were exhausted by meltwater. The vigorous weathering of freshly exposed continental crust provided a new source of iron. The ratios of ${ }^{87} \mathrm{Sr} /{ }^{86} \mathrm{Sr}$ also reflect that the Altungol cap dolostones are formed with a large amount of meteoric water or meltwater

residua depended on weathering residues on the surface of the earth, the CIA and ICV can reflect the weathering degree of earth surface after glaciation. The values of CIA and ICV in this study indicate a warm and wet environment and moderate chemical weathering (Nesbitt and Young 1982).

The iron enrichment in the cap carbonate has been reported in the Rasthof Formation after the Chuos glaciation in Namibia (Hurtgen et al. 2002) and the Etina Formation after Sturtian glaciation in Australia (Swanson-Hysell et al. 2010).
Swanson-Hysell et al. (2010) believed that when ice sheets retreated from the Sturtian glaciation in Australia, the vigorous weathering of freshly exposed continental crust would result in a high proportional delivery of $\mathrm{Fe}$ to $\mathrm{S}$ into the ocean (Hurtgen et al. 2002). In this study, the values of iron maintain at a high level in whole rock. For the acid-insoluble residua results, the values of iron are higher in the samples of $0-1.5-\mathrm{m}$ intervals than $1.5-5-\mathrm{m}$ intervals (Fig. $4 \mathrm{~d}$, e). It means that the sources of iron were different between below $1.5 \mathrm{~m}$ and above $1.5 \mathrm{~m}$. At the initial stage of Altungol cap dolostone formation, the main source of iron is the weathering residues of the parent rocks. With the continental regolith which accumulated during the ice age was exhausted by meltwater, contents of Fe, $\mathrm{Zn}, \mathrm{Ni}$, and $\mathrm{Cu}$ in acid-insoluble residua decreased. Meanwhile, the vigorous weathering of freshly exposed continental crust provided a new source of iron in the warm and wet environment.

The Altungol cap dolostones have high ratios of ${ }^{87} \mathrm{Sr} /{ }^{86} \mathrm{Sr}$ $(\sim 0.7094)$ and the negative correlation between ${ }^{87} \mathrm{Sr} /{ }^{86} \mathrm{Sr}$ and $\delta^{18} \mathrm{O}_{\mathrm{PDB}}$. Liu et al. (2013) suggested that the elevated ${ }^{87} \mathrm{Sr} /{ }^{86} \mathrm{Sr}$ ratios could be understood by the interactions with brines/saline groundwaters. These groundwaters were probably formed by meteoric water (McKirdy et al. 2001) or ice melt seeps (Harris et al. 2007). An alternative explanation for the elevated ${ }^{87} \mathrm{Sr} /{ }^{86} \mathrm{Sr}$ ratios of cap dolostones is that these dolostones are formed in the glacial meltwater (Shields 2005; Hoffman 2011; Liu et al. 2013). Both explanations reflect that the Altungol cap dolostones are formed with a large amount of meteoric water or meltwater.

\section{Conclusions}

In this study, we reported new geochemical results of the Altungol cap dolostones. The enriched $\mathrm{Zn}$ of the acidinsoluble residua and depleted $\delta^{13} \mathrm{C}$ of the whole rock is the evidence of the ocean stratification theory (Shen et al. 2008, 2010; Giddings and Wallace 2009; Shen et al. 2005). The element geochemistry (CIA, ICV, $\mathrm{Cu}, \mathrm{Ni}, \mathrm{Zn}$, and $\mathrm{Fe}$ ) of the acid-insoluble residua displays a warm and wet environment of post-glacial continent. The high ratios of ${ }^{87} \mathrm{Sr} /{ }^{86} \mathrm{Sr}$ and the negative correlation between ${ }^{87} \mathrm{Sr} /{ }^{86} \mathrm{Sr}$ and $\delta^{18} \mathrm{O}_{\mathrm{PDB}}$ reflect that the Altungol cap dolostones are formed with a large amount of meteoric water or meltwater. The high $\sum$ REE $(>10)$ and the absence of Ce-negative anomalies of cap dolostones also reflect input of meltwater. The changes of $\mathrm{Eu} / \mathrm{Eu}^{*}$ and the true positive Ce anomaly in the samples above $3 \mathrm{~m}$ probably reflect the rising sea levels caused by melting glaciers. All of these characteristics and the other geochemical data can be explained by coupling environmental changes in post-glacial ocean and continent, in the Tarim Basin (Fig. 8).

Following the Altungol glaciation, glaciers thawed and meltwater changed ocean chemistry. Oxidation of upwelling 
organic carbon-rich deep-water caused $\delta^{13} \mathrm{C}$ depletion and $\mathrm{Zn}$ enrichment. On the continents, deeply weathered regolith, enriched in $\mathrm{Fe}, \mathrm{Zn}, \mathrm{Ni}$, and $\mathrm{Cu}$, was delivered to the ocean by surface runoff.

Acknowledgments This work is supported by the Major National S\&T Program of China (2011ZX05004-004-005) and the (973) National Basic Research Program of China (Grant 2012CB214801).

Open Access This article is distributed under the terms of the Creative Commons Attribution 4.0 International License (http:// creativecommons.org/licenses/by/4.0/), which permits unrestricted use, distribution, and reproduction in any medium, provided you give appropriate credit to the original author(s) and the source, provide a link to the Creative Commons license, and indicate if changes were made.

\section{References}

Allen PA, Hoffman PF (2005) Extreme winds and waves in the aftermath of a Neoproterozoic glaciation. Nature 433(7022):123-127

Allen AP, Brown JH, Gillooly JF (2002) Global biodiversity, biochemical kinetics, and the energetic-equivalence rule. Science 297(5586): $1545-1548$

Anderson MA, Morel FMM, Guillard RRL (1978) Growth limitation of a coastal diatom by low zinc ion activity. Nature 276(5683):70-71

Asmerom Y, Jacobsen SB, Knoll AH, Butterfield NJ, Swett K (1991) Strontium isotopic variations of Neoproterozoic seawater: implications for crustal evolution. Geochim Cosmochim Acta 55(10):2883-2894

Bao HM, Lyons JR, Zhou CM (2008) Triple oxygen isotope evidence for elevated $\mathrm{CO}_{2}$ levels after a Neoproterozoic glaciation. Nature 453(7194):504-506

Bau M, Dulski P (1999) Comparing yttrium and rare earths in hydrothermal fluids from the Mid-Atlantic Ridge: implications for Y and REE behaviour during near-vent mixing and for the Y/Ho ratio of Proterozoic seawater. Chem Geol 155(1-2):77-90

Bock B, McLennan SM, Hanson GN (1998) Geochemistry and provenance of the middle Ordovician Austin Glen member (Normanskill Formation) and the Taconian orogeny in New England. Sedimentology 45(4):635-655

Bolhar R, Kamber BS, Moorbath S, Fedo CM, Whitehouse MJ (2004) Characterisation of early Archaean chemical sediments by trace element signatures. Earth Planet Sci Lett 222(1):43-60

Bowring S, Myrow P, Landing E, Ramezani J, Grotzinger J (2003) Geochronological constraints on terminal Neoproterozoic events and the rise of Metazoan. Geophys Res Abs 5(1):13219

Brand U, Veizer J (1980) Chemical diagenesis of a multicomponent carbonate system - 1: trace elements. J Sediment Res 50(4):987-998

Chen Y, Zhou X, Yang H (2010) Geochemical research and genesis of dolostones with different crystal characteristics occurring in the Upper Cambrian, central area of Tarim basin [in Chinese with English abstract]. Acta Sedimentol Sin 28(2):209-218

Chen YL, Chu XL, Zhang XL, Zhai MG (2015) Carbon isotopes, sulfur isotopes, and trace elements of the dolomites from the Dengying Formation in Zhenba area, southern Shaanxi: implications for shallow water redox conditions during the terminal Ediacaran. Sci China Earth Sci 58(7):1107-1122

Cox R, Lowe DR, Cullers RL (1995) The influence of sediment recycling and basement composition on evolution of mudrock chemistry in the southwestern United States. Geochim Cosmochim Acta 59(14): 2919-2940
Craig H (1953) The geochemistry of the stable carbon isotopes. Geochim Cosmochim Acta 3(2):53-92

Derry LA, Keto LS, Jacobsen SB, Knoll AH, Swett K (1989) Sr isotopic variations in Upper Proterozoic carbonates from Svalbard and East Greenland. Geochim Cosmochim Acta 53(9):2331-2339

Derry LA, Brasier MD, Corfield REA, Rozanov AY, Zhuravlev AY (1994) $\mathrm{Sr}$ and C isotopes in Lower Cambrian carbonates from the Siberian craton: a paleoenvironmental record during the 'Cambrian explosion. Earth Planet Sci Lett 128(3):671-681

Dulski P (1994) Interferences of oxide, hydroxide and chloride analyte species in the determination of rare earth elements in geological samples by inductively coupled plasma-mass spectrometry. Fresen J Anal Chem 350(4-5):194-203

Evans DA (2000) Stratigraphic, geochronological, and paleomagnetic constraints upon the Neoproterozoic climatic paradox. Am J Sci 300(5):347-433

Fairchild IJ, Kennedy MJ (2007) Neoproterozoic glaciation in the Earth System. J Geol Soc 164(5):895-921

Frimmel HE (2009) Trace element distribution in Neoproterozoic carbonates as palaeoenvironmental indicator. Chem Geol 258(3-4):338-353

Frimmel HE, Klötzli US, Siegfried PR (1996) New Pb-Pb single zircon age constraints on the timing of Neoproterozoic glaciation and continental break-up in Namibia. The Journal of Geology 104(4):459-469

Gao ZJ, Chen KQ (2003) The Nanhua System of Xinjiang and some geological issues of Nanhua System in China. Geological Survey and Research 26(1):8-14

Gao Z, Peng C, Li Y, Qian J, Zhu S (1980) The Sinian System and its glacial deposits in Quruqtagh, Xinjiang. In: Tianjin Institute of Geology and Mineral Resources (ed) Research in Precambrian geology, Sinian Suberathem in China. Tianjin Science and Technology Press, Tianjin, pp. 186-213

Gao ZJ, Zhu CS, Li YA (1984) Precambrian geology in Xinjiang, China. Xinjiang People's Publishing House, Urumuqi, pp. 1-151

Gao ZJ, Chen JB, Lu SN, Peng CW, Qin ZY (1993) The Precambrian geology in northern Xinjiang (Precambrian Geology No. 6). Geology Publication House, Beijing

Gao LZ, Wang ZQ, Xu ZQ, Yang JS, Zhang W (2010) A new evidence from zircon SHRIMP U-Pb dating of the Neoproterozoic diamictite in Quruqtagh area, Tarim basin, Xinjiang, China. Geological Bull China 29(2-3):205-213

Giddings JA, Wallace MW (2009) Sedimentology and C-isotope geochemistry of the 'Sturtian' cap carbonate, South Australia. Sediment Geol 216(1):1-14

Grozinger JP, Knoll AH (1995) Anomalous carbonate precipitates: is the Precambrian the key to the Permian? PALAIOS 10(6):578-596

Guo WD, Yang YP, Shi Q, Hu MH (2003) Statistical study of trace elemental concentrations in major types of organisms from typical Chinese coastal waters. Mar Environ Sci 22(2):1-5

Halverson GP, Hoffman PF, Schrag DP, Maloof AC, Rice AHN (2005) Toward a Neoproterozoic composite carbon-isotope record. Geol Soc Am Bull 117(9-10):1181-1207

Halverson GP, Poitrasson F, Hurtgen MT (2006) Fe isotope composition of Neoproterozoic cap dolostones: implications for snowball seawater composition? Geochim Cosmochim Acta 70(18):A224

Halverson GP, Dudás FÖ, Maloof AC, Bowring SA (2007) Evolution of the $87 \mathrm{Sr} / 86 \mathrm{Sr}$ composition of Neoproterozoic seawater. Palaeogeogr Palaeoclimatol Palaeoecol 256(3):103-129

Harris KJ, Carey AE, Lyons WB, Welch KA, Fountain AG (2007) Solute and isotope geochemistry of subsurface ice melt seeps in Taylor Valley, Antarctica. Geol Soc Am Bull 119(5-6):548-555

Haskin LA, Frey FA (1966) Dispersed and not-so-rare earths. Science 152(3720):299-314 
He JW, Zhu WB, Ge RF (2014) New age constraints on Neoproterozoic diamicites in Kuruktag, NW China and Precambrian crustal evolution of the Tarim Craton. Precambrian Res 241:44-60

Hoffman PF (2011) Strange bedfellows: glacial diamictite and cap carbonate from the Marinoan (635 Ma) glaciation in Namibia. Sedimentology 58(1):57-119

Hoffman PF, Li ZX (2009) A palaeogeographic context for Neoproterozoic glaciation. Palaeogeogr Palaeoclimatol Palaeoecol 277(3): 158-172

Hoffman PF, Schrag DP (2000) Snowball Earth. Sci Am 282(1):68-75

Hoffman PF, Kaufman AJ, Halverson GP, Schrag DP (1998) A Neoproterozoic snowball earth. Science 281(5381):1342-1346

Hoffmann KH, Condon DJ, Bowring SA, Crowley JL (2004) U-Pb zircon date from the Neoproterozoic Ghaub formation, Namibia: constraints on Marinoan glaciation. Geology 32(9):817-820

Huang WH, Bausch WM (1999) The geochemical feature' s comparison between the typical rhythmic bedding limestone and marl of Upper Jurassic Malm in southern Germany. Acta Sedimentol Sin 17(4): 633-637

Hurtgen MT, Arthur MA, Suits NS, Kaufman AJ (2002) The sulfur isotopic composition of Neoproterozoic seawater sulfate: implications for a snowball earth? Earth Planet Sci Lett 203(1):413-429

Jian X, Guan P, Zhang W, Feng F (2013) Geochemistry of Mesozoic and Cenozoic sediments in the northern Qaidam basin, northeastern Tibetan Plateau: implications for provenance and weathering. Chem Geol 360-361:74-88

Kamber BS, Webb GE (2001) The geochemistry of late Archaean microbial carbonate: implications for ocean chemistry and continental erosion history. Geochim Cosmochim Acta 65(15):2509-2525

Kaufman AJ, Jacobsen SB, Knoll AH (1993) The Vendian record of Sr and $\mathrm{C}$ isotopic variations in seawater: implications for tectonics and paleoclimate. Earth Planet Sci Lett 120(3):409-430

Kennedy MJ, Runnegar B, Prave AR, Hoffmann KH, Arthur MA (1998) Two or four Neoproterozoic glaciations? Geology 26(12):1059-1063

Kennedy MJ, Christie-Blick N, Prave AR (2001) Carbon isotopic composition of Neoproterozoic glacial carbonates as a test of paleoceanographic models for snowball Earth phenomena. Geology 29(12):1135-1138

Kirschvink JL (1992) Late Proterozoic low latitude global glaciation: the snowball Earth. In: Schopf JW, Klein C (eds) The Proterozoic biosphere: a multidisciplinary study. Cambridge University Press, Cambridge, pp 51-52

Kou XW, Wang Y, Wei W, He JY, Xu B (2008) The Neoproterozoic Altungol and Huangyanggou formations in Tarim plate: recognized newly glaciation and interglaciation? Acat Petrologica Sinica 24(12):2863-2868

Kuss J, Kremling K (1999) Particulate trace element fluxes in the deep northeast Atlantic Ocean. Deep-Sea Res I 46(1):149-169

Ling HF, Chen X, Li D, Wang D, Shields-Zhou GA, Zhu M (2013) Cerium anomaly variations in Ediacaran-earliest Cambrian carbonates from the Yangtze Gorges area, South China: implications for oxygenation of coeval shallow seawater. Precambrian Res 225:110-127

Liu J, Lu HF, Su X, Chen F, Chen DH, Cheng SH (2012) Element geochemistry of Core BY1 from the northern South China Sea and its paleoenviromental implication. J Trop Oceanogr 31(5):6-11

Liu C, Wang Z, Raub TD (2013) Geochemical constraints on the origin of Marinoan cap dolostones from Nuccaleena Formation, South Australia. Chem Geol 351:95-104

Macdonald FA, Schmitz MD, Crowley JL, Roots CF, Jones DS, Maloof AC, Strauss JV, Cohen PA, Johnston DT, Schrag DP (2010a) Calibrating the cryogenian. Science 327(5970):1241-1243

Macdonald FA, Strauss JV, Rose CV, Dudas FO, Schrag DP (2010b) Stratigraphy of the port Nolloth group of Namibia and South Africa and implications for the age of Neoproterozoic iron formations. Am J Sci 310(9):862-888
McKirdy DM, Burgess JM, Lemon NM, Yu X, Cooper AM, Gostin VA, Jenkins RJF, Both RA (2001) A chemostratigraphic overview of the late Cryogenian interglacial sequence in the Adelaide Fold-Thrust Belt, South Australia. Precambrian Res 106:149-186

Miller NR, Alene M, Sacchi R, Stern RJ, Conti A, Kröner A, Zuppi G (2003) Significance of the Tambien Group (Tigrai, N. Ethiopia) for Snowball Earth events in the Arabian-Nubian Shield. Precambrian Res 121(3):263-283

Nesbitt HW, Markovics G (1997) Weathering of granodioritic crust, longterm storage of elements in weathering profiles, and petrogenesis of siliciclastic sediments. Geochim Cosmochim Acta 61(8):1653-1670

Nesbitt HW, Young GM (1982) Early Proterozoic climates and plate motions inferred from major element chemistry of lutites. Nature 299(5885):715-717

Nothdurft LD, Webb GE, Kamber BS (2004) Rare earth element geochemistry of Late Devonian reefal carbonates, Canning Basin, Western Australia: confirmation of a seawater REE proxy in ancient limestones. Geochim Cosmochim Acta 68(2):263-283

Porter SM, Knoll AH, Affaton P (2004) Chemostratigraphy of Neoproterozoic cap carbonates from the Volta basin, West Africa. Precambrian Res 130(1):99-112

Roddaz M, Viers J, Brusset S, Baby P, Boucayrand C, Hérail G (2006) Controls on weathering and provenance in the Amazonian foreland basin: insights from major and trace element geochemistry of Neogene Amazonian sediments. Chem Geol 226(1):31-65

Rooney AD, Strauss JV, Brandon AD, Macdonald FA (2015) Cryogenian chronology: two long-lasting synchronous Neoproterozoic glaciations. Geology 43(5):459-462

Schoenborn WA, Fedo CM (2011) Provenance and paleoweathering reconstruction of the Neoproterozoic Johnnie Formation, southeastern California. Chem Geol 285(1):231-255

Shen Y, Zhang T, Chu X (2005) C-isotopic stratification in a Neoproterozoic postglacial ocean. Precambrian Res 137(3):243-251

Shen B, Xiao S, Kaufman AJ, Bao H, Zhou C, Wang H (2008) Stratification and mixing of a post-glacial Neoproterozoic Ocean: evidence from carbon and sulfur isotopes in a cap dolostone from Northwest China. Earth Planet Sci Lett 265(1):209-228

Shen B, Xiao S, Zhou C, Kaufman AJ, Yuan X (2010) Carbon and sulfur isotope chemostratigraphy of the Neoproterozoic Quanji Group of the Chaidam Basin, NW China: basin stratification in the aftermath of an Ediacaran glaciation postdating the Shuram event? Precambrian Res 177(3):241-252

Shields GA (2005) Neoproterozoic cap carbonates: a critical appraisal of existing models and the plumeworld hypothesis. Terra Nov. 17:299-310

Shields G, Stille P (2001) Diagenetic constraints on the use of cerium anomalies as palaeoseawater redox proxies: an isotopic and REE study of Cambrian phosphorites. Chem Geol 175(1):29-48

Swanson-Hysell NL, Rose CV, Calmet CC, Halverson GP, Hurtgen MT, Maloof AC (2010) Cryogenian glaciation and the onset of carbonisotope decoupling. Science 328(5978):608-611

Taylor SR, McLennan SM (1995) The geochemical evolution of the continental crust. Rev Geophys 33(2):241-265

Wang YX, Yang JD, Tao XC, Li HM (1988) A study of the Sm-Nd method for fossil mineral rock and its application. J Nanjing Univ 24(2):297-308

Wang S, Ji H, Ouyang Z, Zhou D, Zheng L, Li T (1999) Preliminary study on carbonate rock weathering pedogenesis. Sci China (D) 42 : 572-581

Wang YX, Yang JD, Chen J, Zhang KJ, Rao WB (2007) The Sr and Nd isotopic variations of the Chinese Loess Plateau during the past $7 \mathrm{Ma}$ : implications for the East Asian winter monsoon and source areas of loess. Palaeogeogr Palaeoclimatol Palaeoecol 249(3):351-361

Warren J (2000) Dolomite: occurrence, evolution and economically important associations. Earth Sci Rev 52(1-3):1-81 
Webb GE, Kamber BS (2000) Rare earth elements in Holocene reefal microbialites: a new shallow seawater proxy. Geochim Cosmochim Acta 64(9):1557-1565

Webb GE, Nothdurft LD, Kamber BS, Kloprogge JT, Zhao JX (2009) Rare earth element geochemistry of scleractinian coral skeleton during meteoric diagenesis: a sequence through neomorphism of aragonite to calcite. Sedimentology 56(5):1433-1463

Wei GJ, Liu Y, Li XH, Shao L, Fang DY (2004) Major and trace element variations of the sediments at ODP Site 1144, South China Sea, during the last $230 \mathrm{ka}$ and their paleoclimate implications. Palaeogeogr Palaeoclimatol Palaeoecol 212(3):331-342

Williams GE (1979) Sedimentology, stable-isotope geochemistry and palaeoenvironment of dolostones capping late Precambrian glacial sequences in Australia. J Geol Soc Aust 26(7-8):377-386
Xie SJ, Xie SL, Xie BM (2003) Analysis of Ca, Mg, Fe, Mn, Cu and Zn in algae. Spectrosc Spectr Anal 23(3):615-616

Xu B, Xiao S, Zou H, Chen Y, Li ZX, Song B, Liu D, Zhou C, Yuan X (2009) SHRIMP zircon U-Pb age constraints on Neoproterozoic Quruqtagh diamictites in NW China. Precambrian Res 168(3):247-258

Yang JD, Tao XC, Xue YS (1997) Nd isotopic variations of Chinese seawater during Neoproterozoic through Cambrian. Chem Geol 135(1):127-137

Zhao H, Jones B (2013) Distribution and interpretation of rare earth elements and yttrium in Cenozoic dolostones and limestones on Cayman Brac, British West Indies. Sediment Geol 284-285:26-38

Zhao WZ, Shen AJ, Hu SY, Pan WQ, Zheng JF, Qiao ZF (2012) Types and distributional features of Cambrian-Ordovician dolostone reservoirs in Tarim Basin, northwestern China. Acta Petrol Sin 28(3):758-768 